\title{
In vitro multiple pharmacological targets of Colutea cilicica Boiss. \& Balansa against key enzymes linked to neurodegenerative diseases, diabetes, and hyperpigmentation
}

\author{
Șengül Uysal ${ }^{1}$ (1), Ramazan Ceylan ${ }^{1}$ (D), Abdurrahman Aktumsek ${ }^{1}$ (D), Gökalp Özmen Güler² (1), \\ Carene Picot ${ }^{3}$ (1), Gökhan Zengin²* (D) M. Fawzi Mahomoodally ${ }^{3}$ (C) \\ 'Department of Biology, Science Faculty, Selcuk University, 42250, Konya, Turkey \\ 2Department of Biological Education, Ahmet Kelesoglu Education Faculty, Necmettin Erbakan University, 42090, Konya, Turkey. \\ ${ }^{3}$ Department of Health Sciences, Faculty of Science, University of Mauritius, Réduit, Mauritius
}

ORCID IDs of the authors: S.U. 0000-0003-4562-1719, R.C. 0000-0002-7795-8482, A.A. 0000-0002-5151-2650, G.0.G. 00000003-4771-2489, C.P. 0000-0001-9343-8666, G.Z. 0000-0001-6548-7823, M.F.M. 0000-0001-6548-7823.

Cite this article as: Uysal S, Ceylan R, Aktümsek A, Güler GO, Picot C, Zengin G, Mahomoodally MF. In vitro multiple pharmacological targets of Colutea cilicica Boiss \& Balansa against key enzymes linked to neurodegenerative diseases, diabetes, and hyperpigmentation. Istanbul J Pharm 48 (1): 18-24.

\begin{abstract}
Prevention and treatment of noncommunicable diseases such as neurodegenerative diseases, diabetes, and hyperpigmentation using medicinal plants has attracted increasing attention during the past few decades. In this study, Colutea cilicica Boiss. \& Balansa extracts (ethyl acetate, methanol, and water) were evaluated against key enzymes involved in neurodegenerative diseases, diabetes, and hyperpigmentation. The antioxidant (free radical scavenging, reducing power, $\beta$-carotene/ linoleic acid, and phosphomolybdenum) and metal chelation properties were also investigated. The methanol extracts of $C$. cilicica vigorously inhibited the activities of acetylcholinesterase and butyrylcholinesterase 11.33 and 0.68 mg galantamine equivalents (GALAE)/g extract, respectively). It was observed that $C$. cilicica extracts possessed a higher inhibitory potential for $\alpha$-glucosidase (2.71-1.23 mmol acarbose equivalents (ACAE)/g extract) than that for $\alpha$-amylase $(0.57-0.12 \mathrm{mmol}$ ACAE/g extract). The water extract of $C$. cilicica showed potent radical scavenging capacity against DPPH (2, 2-diphenyl-1-picrylhydrazyl) and ABTS (2,2'-azinobis(3-ethylbenzothiazoline-6-sulfonic acid) ( 42.46 and $57.70 \mathrm{mg}$ trolox equivalents (TE)/g extract, respectively). Phytochemical determination showed that $C$. cilicica water extract (17.26 $\mathrm{mg}$ rutin equivalents (RE)/g extract) was rich in flavonoids compared with ethyl acetate and methanol extracts $(2.78$ and $2.83 \mathrm{mg} \mathrm{RE} / \mathrm{g}$ extract, for the respective extracts). These findings reveal the interesting potential of $C$. cilicica as a valuable source of phytochemicals that can be used against common noncommunicable diseases, particularly against enzymes involved in neurodegenerative diseases.
\end{abstract}

Keywords: Colutea cilica; Alzheimer's disease; diabetes mellitus; natural agents; phytopharmaceuticals.

\section{INTRODUCTION}

Non communicable diseases such as diabetes, and neurodegenerative diseases such as Alzheimer disease (AD) have become a major global health burden (Moreno Cervantes et al 2017). Though the exact cause of AD remains uncertain, hypotheses of the possible pathological pathways have been suggested to affecting mainly the elderly segment of the global population. Factors implicated in the pathogenesis of AD include reduced level of the neurotransmitter acetylcholine, oxidative stress, aggregation of amyloid $\beta$ peptide, and tau protein, and transition metal action (Amadoruge and Barnham 2011; Butterfield et al 2007; Zhao and Zhao 2013). Based on the above mentioned evidences, scientists are aiming at finding therapeutic strategies to manage this debilitating condition. On the other hand, the prevalence of diabetes is on a sharp rise, irrespective of age, affecting younger 
Uysal et al. In vitro multiple pharmacological targets of Colutea cilicica Boiss. \& Balansa against key enzymes linked to neurodegenerative diseases, diabetes, and hyperpigmentation

adults and even children. Panoply of risk factors have been identified such as drastic rise in level of obesity, sedentary lifestyle including low levels of physical activity and familial cases of diabetes (Mutie et al 2017).

Plants have a long and well-known history in the treatment of various human ailments. The diversity of phytoconstituents which exhibit wide spectrum of pharmacological activities, make them ideal candidate for the discovery of novel lead compounds (Jambocus et al 2017). The Colutea genus comprises of about 28 species, forming part of the Fabaceae family (Peşin Süntar et al 2011). These deciduous flowering plants are native to southwest Asia, North Africa, and Southern Europe. Colutea cilicica is chiefly cultivated as an ornamental plant for its attractive yellow flowers and papery like inflated pods containing the seeds (Davis 1997). In Turkey C. cilicica fruits are used to treat abscesses, wounds, and inflammation (Sezik et al 2001). C. cilicica is used against helminthiasis and hypertension in Iraq (Molan et al 2012). D-pinitol isolated from C. cilicica was found to significantly reduce inflammation (Eser et al 2017).

Yet, there is a lack of scientific information regarding the potential of $C$. cilicica in the management of AD. Thus in the present study, we aimed at assessing the possible inhibitory function of $C$. cilicica extracts on enzymes targeted in the management of $A D$, namely cholinesterases. Additionally, we studied the possible inhibitory action of C. cilicica extracts on enzymes related to diabetes, a condition which has been associated to AD. Finally, using a set of in vitro assays we determined the antioxidant potential of C. cilicica extracts. This study was carried out in an endeavor to provide baseline data on the biological properties of a traditionally used medicinal plant for further studies in an attempt of discovering new lead molecules to manage global health problems.

\section{MATERIAL AND METHODS}

\section{Plant Material and extraction procedure}

Aerial parts of Colutea cilicica L. (Soguksu national park, Kızılcahamam, Ankara) was collected during summer 2014 and allowed to air dry at the room temperature. Taxonomic identification was carried out by Dr. Murad Aydın Sanda, senior taxonomist of the Department of Biology, Selcuk University, Turkey .

To produce solvent extracts, the air-dried samples ( $5 \mathrm{~g}$ ) were macerated with $100 \mathrm{~mL}$ of ethyl acetate and methanol at room temperature for $24 \mathrm{~h}$. Further, the extracts were concentrated under vacuum at $40^{\circ} \mathrm{C}$ by using a rotary evaporator. To obtain water extracts, the powdered samples were boiled with 100 $\mathrm{mL}$ distilled water for $20 \mathrm{~min}$. The water extract was lyophilized $\left(-80^{\circ} \mathrm{C}, 48 \mathrm{~h}\right)$. All samples were stored at $+4^{\circ} \mathrm{C}$ in dark until use.

\section{Total phenolics and flavonoids content}

The total phenolics content was determined by Folin-Ciocalteu method (Slinkard and Singleton 1977). Sample solution (0.25
$\mathrm{mL}$ ) was mixed with diluted Folin-Ciocalteu reagent (1 mL, 1:9, $\mathrm{v} / \mathrm{v}$ ) and shaken vigorously. After $3 \mathrm{~min}, \mathrm{Na}_{2} \mathrm{CO}_{3}$ solution (0.75 $\mathrm{mL}, 1 \%)$ was added and the sample absorbance was read at $760 \mathrm{~nm}$ after a $2 \mathrm{~h}$ incubation at room temperature. The results were expressed as gallic acid equivalents (mg GAE/g extract).

For total flavonoid content: sample solution $(1 \mathrm{~mL})$ was mixed with one milliliter of aluminum trichloride (2\%) in methanol. Blanks for each extracts were prepared by adding sample solution $(1 \mathrm{~mL})$ to methanol $(1 \mathrm{~mL})$ without $\mathrm{AlCl}_{3}$. The sample and blank absorbances were read at $415 \mathrm{~nm}$ after a $10 \mathrm{~min}$ incubation at room temperature. The results were evaluated as milligrams of rutin equivalents (mg RE/g extract) (Zengin et al 2016).

\section{Biological activities evaluation}

Antioxidant capacity and enzyme inhibitory effects of C. cilicica extracts were detected for biological abilities. The assays were performed as described by our previous study (Grochowski et al. 2017), and they are summarized in the below.

\section{Antioxidant assays}

\section{DPPH scavenging activity}

After combining $1.0 \mathrm{~mL}$ of extract solution with $4 \mathrm{ml}$ of DPPH $(0.267 \mathrm{mM})$, samples were incubated for 30 minutes in room temperature in darkness. Afterwards, absorbance of samples were measured at $517 \mathrm{~nm}$. Results were calculated as milligrams of trolox equivalents per gram of dry extract (TEs/g).

\section{ABTS radical cation scavenging activity}

Formation of $\mathrm{ABTS}^{+}$radical cation is an effect of incubation in darkness in room temperature mixture of $7 \mathrm{mM} \mathrm{ABTS}$ with $2.45 \mathrm{mM}$ potassium persulfate. Prepared solution was diluted with methanol until its absorbance reached $0.700 \pm 0.02$ at 734 $\mathrm{nm}$. $1 \mathrm{~mL}$ of extract solutions were combined with previously prepared $2 \mathrm{~mL}$ of ABTS+ solution and after 30 min of incubation, absorbance at $734 \mathrm{~nm}$ was measured. Results were expressed as milligrams of trolox equivalents per gram of dry extract.

\section{Phosphomolybdenum method}

$0.3 \mathrm{~mL}$ of tested extract solutions were added to reagent mixture, containing $0.6 \mathrm{M}$ sulfuric acid, $28 \mathrm{mM}$ sodium phosphate and $4 \mathrm{mM}$ ammonium molybdate and after 90 min incubation in $95^{\circ} \mathrm{C}$ absorbances were read in $695 \mathrm{~nm}$ against blank sample $(0.3 \mathrm{~mL}$ methanol with $3 \mathrm{~mL}$ reagent mixture). Millimoles of trolox per gram of dry extract were the measurement unit.

\section{B-carotene/linoleic acid method}

A stock solution of $\beta$-carotene-linoleic acid mixture was prepared as following: $0.5 \mathrm{mg} \beta$-carotene was dissolved in chloroform (1 mL). $25 \mu \mathrm{L}$ linoleic acid and $200 \mathrm{mg}$ Tween 40 was added. Chloroform was completely evaporated using a vacuum evaporator. Then $100 \mathrm{~mL}$ of oxygenated distilled water was added with vigorous shaking; $1.5 \mathrm{~mL}$ of this reaction mixture 
was dispersed to test tubes and sample solution $(0.50 \mathrm{~mL}, 2 \mathrm{mg} /$ $\mathrm{mL}$ ) were added and the emulsion system was incubated for up to $2 \mathrm{~h}$ at $50^{\circ} \mathrm{C}$. The same procedure was repeated with the standard (Butylated hydroxytoluene $(\mathrm{BHT})$ ) and a blank. After this incubation period, the sample absorbance was read at 490 $\mathrm{nm}$. Measurement of absorbance was continued until the color of $\beta$-carotene disappeared. The bleaching rate (R) of $\beta$-carotene was calculated according to Eq. (1).

$R=\left[\frac{(\ln (\mathrm{a} / \mathrm{b})}{\mathrm{t}}\right]$

Where, In=natural log, $a=$ absorbance at time $0, b=$ absorbance at time $t(30,60,90,120 \mathrm{~min})$. The antioxidant activity (AA) was calculated in terms of percent inhibition relative to the control using Eq. (2).

$A A=\left[\frac{\left(R_{\text {Control }}-R_{\text {Sample }}\right)}{R_{\text {Control }}}\right] \times 100$,

\section{Cupric ion reducing (CUPRAC) method}

Extract solutions $(0.5 \mathrm{~mL})$ were added to reaction mixture [CuCl2 (1 mL, $10 \mathrm{mM})$, neocuproine (1 mL, $7.5 \mathrm{mM}), \mathrm{NH} 4 \mathrm{Ac}$ buffer ( $1 \mathrm{~mL}, 1 \mathrm{M}, \mathrm{pH}$ 7.0)] and the absorbance was recorded at $450 \mathrm{~nm}$ after $30 \mathrm{~min}$ of incubation at room temperature. Similarly, a blank sample (prepared in the same manner but without the extract) was prepared and analysed according to this procedure. Milligrams of trolox equivalents per gram of dry extract (TEs/g extract) were the measurement unit.

\section{Ferric reducing antioxidant power (FRAP) method}

Extract solution $(0.1 \mathrm{~mL})$ was added to reagent $(2 \mathrm{~mL})$ in acetate buffer (0.3 M, pH 3.6), 2,4,6-tris(2-pyridyl)-s-triazine (TPTZ) (10 $\mathrm{mM})$ in $40 \mathrm{mM} \mathrm{HCl}$ and ferric chloride $(20 \mathrm{mM})$ in a final ratio of 10:1:1 ( $/ \mathrm{v} / \mathrm{v})$. Then, the absorbance at $593 \mathrm{~nm}$ was read after 30 min of incubation at room temperature. Similarly, a blank sample (prepared in the same manner but without the extract) was prepared. Milligrams of trolox equivalents per gram of dry extract (TEs/g extract) were the measurement unit.

\section{Metal chelating activity on ferrous ions}

Extract solution $(2.0 \mathrm{~mL})$ was added to $\mathrm{FeCl} 2(0.05 \mathrm{~mL}, 2 \mathrm{mM})$, and the reaction was started using $0.2 \mathrm{~mL}$ of $5 \mathrm{mM}$ ferrozine. Similarly, a blank sample for each sample (prepared in the same manner but without ferrozine) was prepared, and all the absorbances were recorded after 10 min of incubation (room temperature) at $562 \mathrm{~nm}$. Milligrams of EDTA equivalents per gram of dry extract (EDTAEs/g extract) were the measurement unit.

\section{Enzyme inhibitory assays}

\section{Cholinesterase inhibition}

After 15 min of incubation at $25^{\circ} \mathrm{C}$ the reaction mixture composed by the extract solution $(50 \mathrm{~mL}$ ), DTNB (3 mM 125 $\mathrm{mL}$ ) and enzyme solution (0.265 u/mL AChE or $0.026 \mathrm{u} / \mathrm{mL}$ BChE) solution ( $25 \mathrm{~mL}$ ) in Tris-HCl buffer ( $\mathrm{pH} 8.0$ ) was added to the substrates [acetylthiocholineiodide (15 mM ATCl) or butyrylthiocholine chloride (1.5 mM BTCl, $25 \mathrm{~mL})$ ]. Likewise, a blank sample (prepared in the same manner but without the extract) was prepared and all the absorbances were recorded at $405 \mathrm{~nm}$ after $15 \mathrm{~min}$. Milligrams of galantamine equivalents per gram of dry extract (GALAEs/g extract) were the measurement unit.

\section{a-Amylase inhibition}

After $10 \mathrm{~min}$ of incubation at $37^{\circ} \mathrm{C}$ the reaction mixture comprising the extract solution ( $25 \mathrm{~mL}$ ), a-amylase solution (10 $\mathrm{u} / \mathrm{mL}, 50 \mathrm{~mL}$ ) in phosphate buffer ( $\mathrm{pH} 6.9$ with $6 \mathrm{mM}$ sodium chloride) was added to the starch solution (50 mL, 0.05\%). The reaction was stopped with the addition of $\mathrm{HCl}(25 \mathrm{~mL}, 1 \mathrm{M})$, and then the iodine-potassium iodide solution was added (100 $\mathrm{mL}$ ). Likewise, a blank sample (prepared in the same manner but without the extract) was prepared, and all the absorbances were recorded at $630 \mathrm{~nm}$ after $10 \mathrm{~min}$ of incubation at $37^{\circ} \mathrm{C}$. Millimoles of acarbose equivalents per gram of dry extract (ACAEs/g extract) were the measurement unit.

\section{a-Glucosidase inhibition}

After $15 \mathrm{~min}$ of incubation at $37^{\circ} \mathrm{C}$ the reaction between the extract solution $(50 \mathrm{~mL})$ glutathione $(0.5 \mathrm{mg} / \mathrm{mL}, 50 \mathrm{~mL})$, a-glucosidase solution $(0.2 \mathrm{u} / \mathrm{mL} 50 \mathrm{~mL})$ in phosphate buffer (pH 6.8) and PNPG (10 mM, $50 \mathrm{~mL}$ ) was stopped with sodium carbonate $(50 \mathrm{~mL}, 0.2 \mathrm{M})$. Likewise, a blank sample (prepared in the same manner but without the extract) was prepared, and all the absorbances were recorded at $400 \mathrm{~nm}$ after 15 min of incubation at $37^{\circ} \mathrm{C}$. Millimoles of acarbose equivalents per gram of dry extract (ACAEs/g extract) were the measurement unit.

\section{Tyrosinase inhibition}

Extract solution $(25 \mathrm{~mL})$ was added to a tyrosinase solution (200 u/mL, $40 \mathrm{~mL}$ ) and phosphate buffer $(40 \mathrm{mM}, 100 \mathrm{~mL}, \mathrm{pH}$ 6.8) in a 96-well microplate and then incubated for $15 \mathrm{~min}$ at $25^{\circ} \mathrm{C}$. The reaction was started using L-DOPA (10 mM, 40 $\mathrm{mL}$ ), and after 10 min of incubation at room temperature all the absorbances were recorded at $492 \mathrm{~nm}$. Similarly, a blank sample (prepared in the same manner but without the extract) was prepared and analysed according to this procedure. Milligrams of kojic acid equivalents per gram of dry extract (KAE/g extract) were the measurement unit.

\section{Statistical Analysis}

All the assays were carried out in triplicate. The results are expressed as mean values and standard deviation (SD). The differences between the different extracts were analyzed using one-way analysis of variance (ANOVA) followed by Tukey's honest significant difference post hoc test with $a=0.05$. This treatment was carried out using SPSS v. 14.0 program.

\section{RESULTS and DISCUSSION}

\section{Enzyme inhibitory effects}

Maintaining the level of acetylcholine in the brain by inhibiting cholinesterase enzymes, is an important strategy for treating AD (Sharififar et al 2012). Cholinesterases namely, acetyl and 
butyryl cholinesterase, terminate neuronal transmission by hydrolyzing acetylcholine, the main neurotransmitter involved in the cholinergic system (Samaradivakara et al 2016). Currently used medication to alleviate AD symptoms carry numerous side effects such as nausea, vomiting, diarrhea, muscle cramps, fatigue, weight loss, confusion, constipation, and dizziness (NI 2017). The need for novel molecules deprived of side effects is of utmost importance. Galantamine used in the treatment of mild to moderate $A D$, is an alkaloid which inhibits acetyl cholinesterase enzyme (Olin and Schneider 2002). With regards to the therapeutic potential of plants, we have studied the cholinesterase inhibition capacity of the ethyl acetate, methanol, and water extracts of $C$. cilicica using in vitro methods. In the present study, the methanol extract of $C$. cilicica actively inhibited AChE and BChE (1.33 and $0.68 \mathrm{mg}$ GALAE/g extract, respectively), compared to a lower activity for ethyl acetate extract (0.99 and 0.09 GALAE/g extract, for respective enzymes) while no activity was recorded for the water extract (Table 1). The observed inhibitory action of $C$. cilicica methanol extract on cholinesterase enzymes might be ascribed to other phytochemicals such as alkaloids, terpenes, and sterols as previously described by Ahmed et al (2013). D-pinitol identified in the leaves of C. cilicica (Eser et al., 2017) was reported to interfere with the accumulation of beta amyloid, involved in Alzheimer's disease (National Library of Medicine, 2017).

Although, tyrosinase was chiefly associated to melanin synthesis and skin hyperpigmentation therapy, evidences highlight that this copper-containing enzyme is linked to Parkinson's disease (PD), the second most common neurodegenerative disorder after AD (Neagu et al 2015). PD is a chronic, progressive movement disorder which affects 6.3 million people worldwide (Coomber et al 2017). PD involves the malfunctioning and apoptosis to neurons in the substantia nigra, which controls movement and coordination (Ellis and Fell 2017). Histological data highlight the presence of neuromelanin in the substantia nigra. Indeed, the dual protective and toxic function of neuromelanin have been reported (Zucca et al 2017). Evidences of the possible role of tyrosinase in the biosynthesis of neuromelanin make its modulation a popular target for the treatment of PD (Cespedes et al 2017). From Table 1 it was observed that C. cilicica extracts possessed variable degree of inhibition against tyrosinase; ethyl acetate extract (54.70 mgKAE/g extract) being the most active and water extract being the least active (42.58 mgKAE/g extract). The observed difference might be associated to the different phytochemical composition of the different extracts (Chigayo et al 2016; Thouri et al 2017).

Magnetic resonance imaging of the brain of elderly suffering from diabetes showed a decrease in the hippocampus size, resulting from reduced neurogenesis and enhanced neuronal death (Pugazhenthi et al 2017). In fact, epidemiological data have revealed that elevated glucose level, the hallmark of diabetes, increases the risk of developing dementia and prompts the exacerbation of mild cognitive impairment of AD. Hyperglyceamia was reported to increase amyloid- $\beta$ levels in the brain by altering neuronal activity via $\mathrm{K}_{\text {ATP }}$ channels (Macauley et al 2015). Epidemiological data also suggest that insulin resistance impaired glucose absorption by neurons, impairing neuronal transmission and cognition (Kandimalla et al 2017). Thus, controlling glucose level in elderly diabetic patients might prevent the onset and/or worsening of cognitive impairments. Alpha-Amylase and a-glucosidase are two enzymes which have been extensively studied for the management of diabetes. a-Amylase is responsible for the hydrolysis of polysaccharides at the early stage of digestion, while a-glucosidase cleaves disaccharides, producing glucose which is absorbed by the enterocytes of the intestinal villi (Zhang et al 2017). From Table 1, it was observed that C. cilicica extracts possessed higher a-glucosidase (2.71-1.23 mmol ACAE/g extract inhibitory potential compared to a-amylase (0.57-0.12 mmol ACAE/g extract). The order of inhibition against a-amylase was as follows ethyl acetate>methanol>water. The same trend was observed against a-glucosidase. From Table 2, it was noted that the ethyl acetate extract (24.77 mgGAE/g extract) of C. cilicica contained the highest amount of phenolic. Indeed, Ademiluyi and Oboh (2013) and Jiang et al (2017) also reported the potent inhibitory effect of phenolic rich extracts on a-amylase and a-glucosidase.

\section{Antioxidant properties}

Oxidative stress is known to play a key role in AD. Oxidative stress refers to the increased production of reactive oxygen species accompanied by the reduced efficiency of the innate antioxidant defense mechanism (Tramutola et al 2017). Reactive oxygen species participate in cellular signaling pathways in vivo, but overproduction induces oxidation of membrane lipids, inactivate enzymes and normal cellular

Table 1. Enzyme inhibitory effects of $\boldsymbol{C}$. cilicica extracts.

\begin{tabular}{|c|c|c|c|c|c|}
\hline Extracts & $\begin{array}{l}\text { AChE inhibition } \\
\text { (mgGALAE/ } \\
\text { g extract) }\end{array}$ & $\begin{array}{c}\text { BChE inhibition } \\
\text { (mgGALAE/ } \\
\text { g extract) }\end{array}$ & $\begin{array}{l}\text { Tyrosinase } \\
\text { (mgKAE/ } \\
\text { g extract) }\end{array}$ & $\begin{array}{c}\alpha \text {-amylase } \\
\text { (mmolACAE/ } \\
\text { g extract) }\end{array}$ & $\begin{array}{c}\alpha \text {-glucosidase } \\
\text { (mmolACAE/ } \\
\text { g extract) }\end{array}$ \\
\hline Ethyl acetate & $0.99 \pm 0.01 *$ & $0.09 \pm 0.01$ & $54.7 \pm 2.28$ & $0.57 \pm 0.076$ & $2.71 \pm 0.05$ \\
\hline Methanol & $1.33 \pm 0.03$ & $0.68 \pm 0.02$ & $52.28 \pm 0.38$ & $0.38 \pm 0.03$ & $2.60 \pm 0.09$ \\
\hline Water & na & na & $42.58 \pm 0.72$ & $0.12 \pm 0.01$ & $1.23 \pm 0.10$ \\
\hline
\end{tabular}




\section{Table 2. Total phenolic and flavonoid contents and total antioxidant, and metal chelating abilities of $C$. cilicica extracts}

\begin{tabular}{|c|c|c|c|c|c|c|c|c|c|}
\hline Extracts & $\begin{array}{c}\text { TPC } \\
\text { (mgGAE/g } \\
\text { extract) }\end{array}$ & $\begin{array}{c}\text { TFC } \\
\text { (mgRE/g } \\
\text { extract) }\end{array}$ & $\begin{array}{c}\text { DPPH } \\
\text { scavenging } \\
\text { (mgTE/g } \\
\text { extract) }\end{array}$ & $\begin{array}{c}\text { ABTS } \\
\text { scavenging } \\
\text { (mgTE/g } \\
\text { extract) }\end{array}$ & $\begin{array}{c}\text { FRAP } \\
\text { (mgTE/g } \\
\text { extract) }\end{array}$ & $\begin{array}{r}\text { CUPRAC } \\
\text { (mgTE/g } \\
\text { extract) }\end{array}$ & $\begin{array}{c}\beta \text {-carotene/ } \\
\text { linoleic acid } \\
\text { assay (inhibition } \\
\text { (\%) at } 2 \mathrm{mg} / \mathrm{ml} \\
\text { concentration) }\end{array}$ & $\begin{array}{l}\text { Phospho- } \\
\text { molybdenum } \\
\text { (mmolTE/g } \\
\text { extract) }\end{array}$ & $\begin{array}{c}\text { Metal } \\
\text { chelating } \\
\text { activity } \\
\text { (mgEDTAE/g } \\
\text { extract) }\end{array}$ \\
\hline Ethyl acetate & $24.77 \pm 1.88^{*}$ & $2.78 \pm 0.21$ & $34.26 \pm 1.09 *$ & $22.67 \pm 0.34$ & $32.00 \pm 1.92$ & $56.21 \pm 4.25$ & $91.96 \pm 0.20$ & $1.88 \pm 0.01$ & $6.78 \pm 0.03$ \\
\hline Methanol & $17.82 \pm 1.87$ & $2.83 \pm 0.10$ & $12.89 \pm 2.75$ & $16.22 \pm 1.25$ & $21.36 \pm 1.26$ & $49.97 \pm 1.99$ & $91.44 \pm 0.50$ & $1.61 \pm 0.01$ & $0.65 \pm 0.01$ \\
\hline Water & $20.25 \pm 0.73$ & $17.26 \pm 0.16$ & $42.46 \pm 0.08$ & $57.70 \pm 1.22$ & $58.48 \pm 0.34$ & $74.68 \pm 0.66$ & $86.12 \pm 0.40$ & $0.91 \pm 0.04$ & $2.72 \pm 0.02$ \\
\hline $\mathrm{BHT}$ & nt & nt & nt & nt & nt & nt & $91.70 \pm 0.39$ & nt & nt \\
\hline
\end{tabular}

functioning, damage proteins and DNA, thus contributing to AD (García-Blanco et al 2017). In the present study, we assessed the antioxidant potential of C. cilicica extracts by using a set of antioxidant assays. Free radicals are unsw molecules containing one or more unpaired electrons, making them highly reactive (Poprac et al 2017). ABTS and DPPH radicals have been extensively used in vitro to provide an insight of the radical scavenging capacity of antioxidant molecules. The water extract of C. cilicica showed potent radical scavenging capacity against DPPH and ABTS (42.46 and $57.70 \mathrm{mgTE} / \mathrm{g}$ extract). Phytochemical determination showed that C. cilicica water extract (17.26 mg RE/g extract) was rich in flavonoids as compared to ethyl acetate and methanol extracts (2.78 and $2.8326 \mathrm{mg} \mathrm{RE} / \mathrm{g}$ extract, for respective extracts). This finding is in accordance with the statements of Pizzino et al (2017) and Kumar and Pandey (2013). The FRAP and CUPRAC assays were employed to evaluate the reducing potential of $C$. cilicica extracts. The redox potential of phytochemicals makes them potent reducing agents (Al-Rimawi et al 2016). As noted from Table 2, water extract of $C$. cilicica was a potential reducing agent (58.48 and $74.68 \mathrm{mg}$ TE/g extract, for FRAP and CUPRAC assays respectively). This extract contained the highest amount of flavonoids, which was previously reported to act as a potent reducing agent (Ghasemzadeh and Ghasemzadeh 2011). $\beta$-carotene/linoleic acid and phosphomolybdenum assays are also currently used to provide an insight of the oxidant scavenging potential of plant phytochemicals. From Table 2, it was observed that the extracts of C. cilicica (value ranging from 91.96 to $89.12 \%$ inhibition as compared to $91.70 \%$ inhibition for BHT) prevented $\beta$-carotene discoloration induced by linoleic acid oxidation in the following order ethyl acetate>methanol>water. The same trend was observed for the phosphomolybdenum assay.

Metal ions such as copper, zinc, and iron, are involved in neuron signaling, apoptosis, cell proliferation, inflammation, and oxidative stress control (Kepp 2017). Disruption of the homeostasis of metal ions was associated to amyloid- $\beta$ deposits and tau phosphorylation, resulting in the formation of neurofibrillary tangles and senile plaque formation, which fuel AD (Wang and Wang 2017). Finding molecules possessing metal chelating abilities might serve in the management of AD. From the present study ethyl acetate extract $(6.78 \mathrm{mg}$ EDTAE/g extract) of C. cilicica showed the most potent metal chelating activity followed by water extract (2.72 mg EDTAE/g extract) and methanol extract (0.65 mg EDTAE/g extract). Total phenolic content determination followed the same trend (Table 2), suggesting that phenolic composition of the extracts obtained from solvents of different polarities affected the observed chelating potential.

\section{CONCLUSION}

$A D$ is a complex, multifactorial disorder affecting the elderly segment of the world's population. While existing treatments are palliative and offer no improvement of the disease conditions, the major concern is the discovery of new effective agents. This study provides an insight on the potential of $C$. cilicica in the management of AD. C. cilicica acted as cholinesterase inhibitor. C. cilicica was also found to modulate the action of other enzymes namely a-amylase and a-glucosidase, which are the main targets of glycaemic control. Indeed, chronic dyshomeostasis of blood glucose level was linked to AD. Data collected from the present study showed that C. cilicica water extract was rich in flavonoids and possessed potent reducing potential. C. cilicica previously reported to be used in traditional medicine, might also be used as a natural source of antioxidants Therefore, C. cilicica merits further investigation as it is a source of valuable multitarget compounds for the management of AD.

\section{ACKNOWLEDGEMENTS}

The authors declared that there are no conflicts. This research was also supported by The Scientific and Technological Research Council of Turkey (TUBITAK) (Project Number: 113Z892).

\section{REFERENCES}

- $\quad$ Ademiluyi AO, Oboh G (2013). Soybean phenolic-rich extracts inhibit key-enzymes linked to type 2 diabetes (alpha-amylase and alpha-glucosidase) and hypertension (angiotensin । converting enzyme) in vitro. Exp Toxicol Pathol 65(3): 305-309. 
- $\quad$ Ahmed F, Ghalib RM, Sasikala P, Ahmed KKM (2013). Cholinesterase inhibitors from botanicals. Pharmacogn Rev $\mathbf{7}(14)$ : 121-130.

- $\quad$ Al-Rimawi F, Rishmawi S, Ariqat SH, Khalid MF, Warad I, Salah Z (2016). Anticancer Activity, Antioxidant Activity, and Phenolic and Flavonoids Content of Wild Tragopogon porrifolius Plant Extracts. J Evid Based Complementary Altern Med 2016: 1-7

- Amadoruge PC, Barnham KJ (2011). Alzheimer's disease and metals: a review of the involvement of cellular membrane receptors in metallosignalling. Int J Alzheimers Dis 2011: 1-9.

- Botić $T$, Defant $A$, Zanini $P$, Žužek $M C$, Frangež $R$, Janussen $D$, Kersken D, Knez Ž, Mancini I, Sepčić K (2017). Discorhabdin alkaloids from Antarctic Latrunculia spp. sponges as a new class of cholinesterase inhibitors. Eur J Med Chem 136: 294-304.

- $\quad$ Butterfield DA, Reed T, Newman SF, Sultana R (2007). Roles of amyloid $\beta$-peptide-associated oxidative stress and brain protein modifications in the pathogenesis of Alzheimer's disease and mild cognitive impairment. Free Radic Biol Med 43(5), 658-677.

- Cespedes CL, Balbontin C, Avila JG, Dominguez M, Alarcon J, Paz C, Burgos V, Ortiz L, Peñaloza-Castro I, Seigler DS. (2017). Inhibition on cholinesterase and tyrosinase by alkaloids and phenolics from Aristotelia chilensis leaves. Food Chem Toxicol 109: 984-995.

- Chigayo K, Mojapelo PEL, Mnyakeni-Moleele S, Misihairabgwi JM (2016). Phytochemical and antioxidant properties of different solvent extracts of Kirkia wilmsii tubers. Asian Pac J Trop Biomed 6(12): 1037-1043.

- Coomber R, Alshameeri Z, Masia F, Mela F, Parker MJ (2017). Hip fractures and Parkinson's disease: a case series. Injury 48: 27302735.

- Davis P (1997). Flora of Turkey and the East Aegean Islands. (Vol. 3): Edinburgh Univ. Press, Edinburgh.

- Ellis JM, Fell MJ (2017). Current approaches to the treatment of Parkinson's Disease. Bioorg Med Chem Lett 18: 4247-4255.

- Eser F, Altundag EM, Gedik G, Demirtas I, Onal A, Selvi B (2017). Anti-inflammatory effect of D-pinitol isolated from the leaves of Colutea cilicica Boiss et Bal. on K562 cells. Turk J Biochem 42(4): 445-450.

- García-Blanco A, Baquero M, Vento M, Gil E, Bataller L, CháferPericás C (2017). Potential oxidative stress biomarkers of mild cognitive impairment due to Alzheimer disease. J Neurol Sci 373 295-302.

- Ghasemzadeh A, Ghasemzadeh N (2011). Flavonoids and phenolic acids: Role and biochemical activity in plants and human. J Med Plants Res 5(31): 6697-6703.

- Grochowski DM, Uysal S, Aktumsek A, Granica S, Zengin G, Ceylan R, Locatelli M, Tomczyk, M. (2017). In vitro enzyme inhibitory properties, antioxidant activities, and phytochemical profile of Potentilla thuringiaca. Phytochem Let 20: 365-372.

- Jambocus NGS, Ismail A, Khatib A, Mahomoodally F, Saari N, Mumtaz MW, Hamid AA (2017). Morinda citrifolia L. leaf extract prevent weight gain in Sprague-Dawley rats fed a high fat diet. Food Nutr Res 61 (1): 1-14.

- Jiang P, Xiong J, Wang F, Grace MH, Lila MA, Xu R. (2017). Alphaamylase and alpha-glucosidase Inhibitory Activities of Phenolic Extracts from Eucalyptus grandis $\times$ E. urophylla Bark. J Chem 2017: $1-7$.

- Kandimalla R, Thirumala V, Reddy PH (2017). Is Alzheimer's disease a type 3 diabetes? A critical appraisal. BBA-Mol Basis Dis 1863(5): 1078-1089.

- Kepp KP (2017). Alzheimer's disease: How metal ions define $\beta$-amyloid function. Coord Chem Rev 351:127-159
Kumar S, Pandey AK (2013). Chemistry and biological activities of flavonoids: an overview. The Scientific World Journal, 2013: 1-16.

- Macauley SL, Stanley M, Caesar EE, Yamada SA, Raichle ME, Perez R, Mahan TE, Sutphen CL, Holtzman DM (2015). Hyperglycemia modulates extracellular amyloid- $\beta$ concentrations and neuronal activity in vivo. J Clin Invest 125(6): 2463-2967.

Molan AL, Faraj AM, Mahdy AS (2012). Antioxidant activity and phenolic content of some medicinal plants traditionally used in Northern Iraq. Phytopharmacol 2(2): 224-233.

- Moreno Cervantes C, Mimenza Alvarado A, Aguilar Navarro S, Alvarado Avila P, Gutierrez Gutierrez L, Juarez Arellano S, Avila Funes JA (2017). Factors associated with mixed dementia vs Alzheimer disease in elderly Mexican adults. Neurologia, 32(5): 309-315. doi: 10.1016/j.nrl.2015.12.006

- Mutie PM, Giordano GN, Franks PW (2017). Lifestyle precision medicine: the next generation in type 2 diabetes prevention?. BMC Medicine 15(1): 1-11.

National Library of Medicine (2017). https://clinicaltrials.gov/ct2/ show/record/NCT00470418

Neagu E, Paun G, Albu C, Radu GL (2015). Assessment of acetylcholinesterase and tyrosinase inhibitory and antioxidant activity of Alchemilla vulgaris and Filipendula ulmaria extracts. J Taiwan Inst Chem Eng 52: 1-6.

- NI (2017). https://www.nia.nih.gov/health/how-alzheimersdisease-treated

Olin J, Schneider L (2002). Galantamine for Alzheimer's disease. Cochrane Database Syst Rev 3: CD001747-CD001747.

Omar SH, Scott CJ, Hamlin AS, Obied HK (2017). The protective role of plant biophenols in mechanisms of Alzheimer's disease. $J$ Nutr Biochem 47: 1-20.

Peşin Süntar I, Koca U, Küpeli Akkol E, Yılmazer D, Alper M. (2011). Assessment of wound healing activity of the aqueous extracts of Colutea cilicica Boiss. \& Bal. fruits and leaves. J Evid Based Complementary Altern Med 2011:1-7.

Pizzino G, Irrera N, Cucinotta M, Pallio G, Mannino F, Arcoraci V, Squadrito F, Altavilla D, Bitto A (2017). Oxidative Stress: Harms and Benefits for Human Health. Oxid Med Cell Longev 2017, 1-13.

- Poprac P, Jomova K, Simunkova M, Kollar V, Rhodes CJ, Valko M (2017). Targeting Free Radicals in Oxidative Stress-Related Human Diseases. Trends Pharmacol Sci 38, 592-607.

Pugazhenthi S, Qin L, Reddy PH (2017). Common neurodegenerative pathways in obesity, diabetes, and Alzheimer's disease. BBA-Mol Basis Dis 1863(5): 1037-1045.

Samaradivakara SP, Samarasekera R, Handunnetti SM,Weerasena OJ (2016). Cholinesterase, protease inhibitory and antioxidant capacities of Sri Lankan medicinal plants. Ind Crops Prod 83: 227234.

Sezik E, Yeşilada E, Honda G, Takaishi Y, Takeda Y, Tanaka T. (2001). Traditional medicine in Turkey $X$. Folk medicine in central Anatolia. J Ethnopharmacol 75(2): 95-115.

- Sharififar F, Moshafi M, Shafazand E, Koohpayeh A (2012). Acetyl cholinesterase inhibitory, antioxidant and cytotoxic activity of three dietary medicinal plants. Food Chem 130(1): 20-23.

Slinkard K, Singleton VL (1977). Total phenol analysis: automation and comparison with manual methods. Am J Enol Viticult $\mathbf{2 8}(1)$, 49-55.

Thouri A, Chahdoura H, El Arem A, Omri Hichri A, Ben Hassin R, Achour L. (2017). Effect of solvents extraction on phytochemical components and biological activities of Tunisian date seeds (var. Korkobbi and Arechti). BMC Complement Alt Med 17(1): 1-10. 
Istanbul J Pharm 48 (1): 18-24

- Tramutola A, Lanzillotta C, Perluigi M, Butterfield DA (2017). Oxidative stress, protein modification and Alzheimer disease. Brain Res Bull 133: 88-96.

- $\quad$ Wang P, Wang ZY (2017). Metal ions influx is a double edged sword for the pathogenesis of Alzheimer's disease. Ageing Res Rev 35: 265-290.

- Zengin G, Nithiyanantham S, Locatelli M, Ceylan R, Uysal S, Aktumsek A, Selvi PK, Maskovic P (2016). Screening of in vitro antioxidant and enzyme inhibitory activities of different extracts from two uninvestigated wild plants: Centranthus longiflorus subsp. Iongiflorus and Cerinthe minor subsp. auriculata. Eur J Integr Med 8(3): 286-292.
Zhang Bw, Xing Y, Wen C, Yu Xx, Sun W, Xiu Zl, Dong, Ys (2017). Pentacyclic triterpenes as a-glucosidase and a-amylase inhibitors: Structure-activity relationships and the synergism with acarbose. Bioorg Med Chem Lett 27: 5065-5070.

- Zhao Y, Zhao B (2013). Oxidative stress and the pathogenesis of Alzheimer's disease. Oxid Med Cell Longev 2013: 1-10.

- Zucca FA, Segura-Aguilar J, Ferrari E, Muñoz P, Paris I, Sulzer D, Sarna T, Casella L, Zecca L (2017). Interactions of iron, dopamine and neuromelanin pathways in brain aging and Parkinson's disease. Prog Neurobio/ 155: 96-119. 